\title{
Parallel Down-Regulation of FOX01, PPAR $\gamma$ and Adiponectin mRNA Expression in Visceral Adipose Tissue of Class III Obese Individuals
}

\author{
Thais Ortiz Hammes ${ }^{a} \quad$ Cíntia dos Santos Costa $^{a} \quad$ Francieli Rohden ${ }^{a}$ \\ Rogério Margis ${ }^{a}$ b Jussara Carnevale de Almeida ${ }^{c}$ \\ Alexandre Vontobel Padoin ${ }^{d}$ Cláudio Cora Mottin ${ }^{d}$ Regina Maria Guaragna ${ }^{a}$ \\ a Departamento de Bioquímica, , ${ }^{b}$ Centro de Biotecnologia, , ${ }^{c}$ Faculdade de Medicina,UFRGS, \\ ${ }^{d}$ Centro de Obesidade e Síndrome Metabólica, PUCRS, Porto Alegre, Brazil
}

\author{
Key Words \\ Adipose tissue $\cdot$ Obesity $\cdot$ Adiponectin $\cdot$ FOXO1
}

\begin{abstract}
Objective: Adipose tissue is responsible for secretion of several cytokines that mediate systemic effects on obesity and insulin resistance. Subcutaneous abdominal adipose tissue (SAT) and visceral adipose tissue (VAT) are metabolically different and have differences in their gene expression profile. Our study evaluated the expression of adiponectin, FOXO1, PPAR $\gamma$, and SIRT1 in VAT and SAT of non-obese and class III obese subjects. Methods: The adipose tissue samples were obtained by surgery. Reverse transcripts of studied genes were determined by quantitative real-time polymerase chain reaction (qRT-PCR). Results: Comparing the different lipid depots, adiponectin expression was lower only in VAT of obese individuals ( $p=0.043$ ); FOXO1 and PPAR y levels were decreased in VAT of both groups. When non-obese and obese were compared, only adiponectin expression was lower in SAT and in VAT of obese subjects ( $p=0.004$ and $p=0.002$, respectively). No difference was found with regard to SIRT1 levels in VAT or SAT in both groups. FOXO1 expression in SAT of obese subjects had a negative correlation with age $(r=-0.683 ; p=0.029)$ and triglyceride serum levels $(r=-0.794 ; p=0.006)$. Conclusion: The decrease mRNA expression of this genes in VAT, responsible for central adiposity, may be associated with an increased risk of obesity and co-morbidities.
\end{abstract}


Hammes et al.: Parallel Down-Regulation of FOXO1, PPARg and Adiponectin mRNA

Expression in Visceral Adipose Tissue of Class III Obese Individuals

\section{Introduction}

The global epidemic of obesity is a major public health problem, which is driven largely by its co-morbidities including insulin resistance, type 2 diabetes, dyslipidemia, and cancer $[1,2]$. The etiology of obesity is complex, with environmental and genetic influences [3]. The basic mechanism to its development is an imbalance between the energy ingested and expended by the body. The excess of energy ingested is stored as adipose tissue [4]. However, we know little about the participation of transcription factors in this modulation.

Adipose tissue depots are anatomically and metabolically different and have differences in their gene expression profile. The abdominal adipose tissue can be divided in subcutaneous (SAT) and visceral (VAT) adipose tissues [5]. Visceral adipocytes are generally believed to be hyperlipolytic by being highly responsive to catecholamine stimulation and more resistant to the antilipolytic effect of insulin, when compared to subcutaneous fat [6].

The peroxisome proliferator-activated receptors (PPARs) are members of the nuclear receptor superfamily involved in the transcriptional regulation of lipid metabolism genes, energy balance, and inflammation. There are three isotypes: PPAR $\alpha, \operatorname{PPAR} \beta / \delta$ and PPAR $\gamma$ [9]. PPAR $\gamma$ is highly expressed in adipose tissue [7]. Its activation promotes lipid synthesis and storage in white adipose tissue as well as preadipocyte differentiation to mature adipocytes [8]. In spite of this, PPAR $\gamma$ activation is highly associated with increases of insulin sensitivity [9]. Similarly, adiponectin is also related to improvement of insulin resistance. Adiponectin is an abundant protein present in the blood and specifically derived from adipose tissue and may be a link between obesity and the development of insulin resistance [10]. Adiponectin levels are reduced in obese individuals, particularly among subjects with excess visceral adiposity [11].

FOX01, a transcription factor member of the forkhead box-containing protein-O superfamily, is predominant in insulin-responsive tissues, including adipose tissue [12]. FOXO1 is a negative regulator of insulin sensitivity in adipocytes [13]. In response to insulin, it is phosphorylated through the PI3K-dependent pathway, resulting in its nuclear exclusion and inhibition of target gene expression [14]. A study carried out investigating the effects of FOXO1 on PPAR $\gamma$ gene expression of human adipocytes observed that FOXO1 expression dose-dependently repressed PPAR $\gamma$ transcription [15].

Sirtuins (SIRT) are members of the mammalian $\mathrm{NAD}^{+}$-dependent histone deacetylase family [16]. There are seven mammalian sirtuins (SIRT 1-7), and SIRT1 has been the most studied. This protein has been implicated in the control of lipid and glucose metabolism by regulating many important transcription factors such as PPAR $\gamma$ and FOXO1 [17,18]. Bäckesjö et al. [19] showed that activation of SIRT1 blocked adipocyte development and increased the expression of osteoblast markers in the rat mesenquimal cell line C3H10T1/2. In spite of this, Qiao et al. [20] demonstrated that SIRT1 increased adiponectin transcription, a protein associated with insulin sensibility, by activating FOXO1 expression in 3T3-L1 adipocytes.

SAT and VAT are metabolically different, but there are few studies about the levels of FOX01, adiponectin, PPAR $\gamma$, and SIRT1 expression in these tissues. Furthermore, in the present study, we examined expressions of these genes in SAT and VAT of non-obese and class III obese subjects.

\section{Material and Methods}

Samples

Samples of SAT and VAT were obtained from 13 subjects with class III obesity (BMI $\geq 40 \mathrm{~kg} / \mathrm{m}^{2}$ ), who underwent Roux-en-Y gastric bypass at the Centro de Obesidade e Síndrome Metabólica of Hospital São Lucas of Pontifícia Universidade Católica of Rio Grande do Sul (COM/PUCRS, Brazil). The extensive 
Hammes et al.: Parallel Down-Regulation of FOXO1, PPARg and Adiponectin mRNA

Expression in Visceral Adipose Tissue of Class III Obese Individuals

Table 1. Anthropometric and biological parameters of subjects with obesity class III $(n=13)$

\begin{tabular}{ll}
\hline Characteristics & Values \\
\hline Age, years & $33(28-38)$ \\
BMI, kg/m² & $49.6(43.8-55.3)$ \\
Waist circumference, $\mathrm{cm}$ & $131.1(121.7-140.5)$ \\
Fasting glucose, $\mathrm{mg} / \mathrm{dl}$ & $128(72-184)$ \\
Fasting insulin, $\mu \mathrm{U} / \mathrm{ml}$ & $26.4(18.6-34.2)$ \\
HOMA-IR, mmol/l $\times \mu \mathrm{U} / \mathrm{ml}$ & $8.2(4.7-11.7)$ \\
Total cholesterol, $\mathrm{mg} / \mathrm{dl}$ & $203(167-239)$ \\
HDL-cholesterol, $\mathrm{mg} / \mathrm{dl}$ & $47.4(38.7-56)$ \\
LDL-cholesterol, $\mathrm{mg} / \mathrm{dl}$ & $116.6(97.8-135.3)$ \\
Triglycerides, mg/dl & $171(101.5-226.5)$ \\
\hline \multicolumn{2}{c}{ aValues shown are mean values $(95 \%$ confidence interval). } \\
\hline
\end{tabular}

clinical and laboratory data routinely collected for each obese individual are given in table 1 . To evaluate insulin resistance, we used a mathematical model of Homeostasis Assessment Model Insulin Resistance (HOMA-IR). It is calculated as follows: HOMA-IR = Fasting plasma insulin level (mg/dl) $\times$ (Fasting plasma glucose level $(\mu \mathrm{U} / \mathrm{ml}) \times 0.05551 / 22.5$ [21]. Similar samples of VAT and SAT were obtained from 10 non-obese individuals who underwent elective surgery; their age range was 22-55 years, with BMI of $17.9-29.0 \mathrm{~kg} / \mathrm{m}^{2}$, fasting glucose of $85-105 \mathrm{mg} / \mathrm{dl}$, and serum triglycerides of $87-120 \mathrm{mg} / \mathrm{dl}$. Patients' weights had been stable for at least 1 year. None of the subjects were taking any medications affecting adipocyte metabolism.

The study was approved by Ethics Committee of Universidade Federal do Rio Grande do Sul (nº 2007/936). All subjects were informed about the aim of the study and signed the informed consent form.

\section{Analysis of mRNA Expression}

Adipose tissue samples were collected and immediately immersed in TRIzol reagent (Invitrogen, Darmstadt, Germany). Approximately $2 \mu \mathrm{g}$ of total RNA were added to each cDNA synthesis reaction using the M-MLV Reverse Transcriptase (Invitrogen). Reactions were performed at $42{ }^{\circ} \mathrm{C}$ for $1 \mathrm{~h}$ using the primer T23V (5' TTT TTT TTT TTT TTT TTT TTT TTV 3'). The cDNA samples were stored at $-20^{\circ} \mathrm{C}$. The sequences of the primer pairs used in PCR reactions are listed in table 2. Applied-Biosystems 7500 real-time cycler (Applied Biosystems, Carlsbad, CA, USA) was used to carry out the quantitative real-time PCR (qRT-PCR). Reaction settings were composed of an initial denaturation step of $5 \mathrm{~min}$ at $95^{\circ} \mathrm{C}$ followed by 40 cycles of $15 \mathrm{~s}$ at $95^{\circ} \mathrm{C}, 10 \mathrm{~s}$ at $60^{\circ} \mathrm{C}, 15 \mathrm{~s}$ at $72^{\circ} \mathrm{C}$ and $35 \mathrm{~s}$ at $60^{\circ} \mathrm{C}$; samples were held for $15 \mathrm{~s}$ at $95^{\circ} \mathrm{C}$ for annealing and then heated for $1 \mathrm{~min}$ at $60^{\circ} \mathrm{C}$ with a ramp of $0.1^{\circ} \mathrm{C} / \mathrm{s}$ to acquire data to produce the denaturing curve of the amplified products. qRT-PCRs were made in a final volume of $20 \mu \mathrm{l}$, composed of $10 \mu \mathrm{l}$ of each reverse transcription sample diluted 40-100 times, $2 \mu \mathrm{l} 10$ times PCR buffer, $1.2 \mu \mathrm{l}$ of $50 \mathrm{mmol} / \mathrm{l} \mathrm{MgCl}_{2}$, $0.1 \mu \mathrm{l}$ of $5 \mathrm{mmol} / \mathrm{l} \mathrm{dNTPs}, 0.4 \mu \mathrm{l}$ of $10 \mu \mathrm{mol} / \mathrm{l}$ primer pairs, $4.25 \mu \mathrm{l}$ of water, $2.0 \mu \mathrm{l}$ of SYBR green $(1: 10,000$; Molecular Probes ${ }^{\circledR}$, Invitrogen), and $0.05 \mu$ l of Platinum Taq DNA polymerase ( $5 \mathrm{U} / \mu \mathrm{l}$ ) (Invitrogen). Each sample was run in quadruplicate.

\section{Data Analysis}

Gene expression was quantified using the $2^{-} \Delta \Delta^{\mathrm{Ct}}$ (threshold cycle) method [22]. For each sample, a $\triangle \mathrm{C}_{\mathrm{T}}$ value was obtained by subtracting the beta-2-microglobulin (B2M) $\mathrm{C}_{\mathrm{T}}$ value from the $\mathrm{C}_{\mathrm{T}}$ value of the interest gene. To calculate the difference between SAT and VAT in obese and non-obese, the $\triangle C_{T}$ mean value obtained for the SAT of non-obese was used to calculate the $\triangle \triangle \mathrm{Ct}$ of each gene $\left(2^{-} \triangle \triangle^{\mathrm{Ct}}\right)$.

\section{Statistics}

To compare adiponectin, FOX01, PPAR $\gamma$, and SIRT1 mRNA expression between the two depots (SAT and VAT), we used the non-parametric Wilcoxon test. To compare the expression pattern between nonobese and obese we used the non-parametric Mann-Whitney U test. Data are expressed as median (25th- 
Hammes et al.: Parallel Down-Regulation of FOXO1, PPARg and Adiponectin mRNA Expression in Visceral Adipose Tissue of Class III Obese Individuals

Table 2. Oligonucleotides used in qRT-PCR reactions

\begin{tabular}{ll}
\hline Gene & Sequence \\
\hline B2M & $\begin{array}{l}\text { Forward 5'-TGCTGTCTCCATGTTTGATGTATCT-3' } \\
\text { Reverse 5'-TCTCTGCTCCCCACCTCTAAGT-3' }\end{array}$ \\
Adiponectin & $\begin{array}{l}\text { Forward 5'-TGGTGAGAAGGGTGAGAA-3' } \\
\text { Reverse 5'-AGATCTTGGTAAAGCGAATG-3' }\end{array}$ \\
F0X01 & Forward 5'-TGGACATGCTCAGCAGACATC-3' \\
& Reverse 5'-TTGGGTCAGGCGGTTCA-3' \\
PPAR $\gamma$ & Forward 5'-AGGCCATTTTCTCAAAC-3' \\
SIRT1 & Reverse 5'-AGAAATGCTGGAGAAGTCAACA-3' \\
& Forward 5'-GAGTGGCAAAGGAGCAGA-3' \\
& Reverse 5'-TCTGGCATGTCCCACTATC-3' \\
\hline
\end{tabular}

75th percentile). We used Spearman correlation test $(r S)$ to correlate the characteristics of patients with class III obesity and adiponectin, FOX01, PPAR $\gamma$ and SIRT1 mRNA expression in both tissues, VAT and SAT. All variables were examined for normality using the Kolmogorov-Smirnov test. P values $<0.05$ (twotailed) were considered to be statistically significant. SPSS 14.0 (SPSS Inc., Chicago, IL, USA) was used for the analyses.

\section{Results}

The relative expression of adiponectin, FOX01, PPAR $\gamma$, and SIRT1 mRNA in VAT and SAT of non-obese and obese subjects were obtained by RT-PCR. Table 3 reflects the mRNA expression profile of adiponectin, FOX01, PPAR $\gamma$, and SIRT1 in VAT and SAT of non-obese and class III obese individuals. In non-obese subjects, FOXO1 $(\mathrm{p}=0.046)$ and PPAR $\gamma(\mathrm{p}=$ $0.028)$ expressions were lower in VAT when compared to SAT. SIRT $(p=0.116)$ and adiponectin $(\mathrm{p}=0.080)$ mRNA expression showed no difference between the tissues in non-obese individuals. When analyzing the expression patterns in obese individuals, we found a lower expression of adiponectin $(\mathrm{p}=0.043)$, FOXO1 $(\mathrm{p}=0.038)$, and PPAR $\gamma(\mathrm{p}=0.028)$ in VAT compared to SAT. However, SIRT mRNA expression showed no difference between fat depots $(\mathrm{p}=0.465)$.

When we compared the expression patterns between non-obese and class III obese individuals, we found lower adiponectin mRNA levels in the obese than in the non-obese group in both adipose tissues, SAT $(p=0.004)$ and VAT $(p=0.002)$. However, in SAT and VAT, the mRNA expression of FOXO1, PPAR $\gamma$, and SIRT1 showed no difference between non-obese and obese subjects.

We also performed correlation analysis between anthropometric and biochemical parameters of class III obese subjects with adiponectin, FOXO1, SIRT1, and PPAR $\gamma$ mRNA expression in both tissues, VAT and SAT. We found that levels of FOXO1 mRNA expressed in SAT (fig. 1) has an inverse correlation with age $(r=-0.683 ; \mathrm{p}=0.029)$ and triglycerides serum levels $(r=-0.794 ; \mathrm{p}=0.006)$. 
Table 3. Adiponectin, FOX01, PPAR $\gamma$, and SIRT1 mRNA expression in intra-abdominal adipose tissue of non-obese and class III obese subjects ${ }^{\mathrm{a}}$

Hammes et al.: Parallel Down-Regulation of FOXO1, PPARg and Adiponectin mRNA Expression in Visceral Adipose Tissue of Class III Obese Individuals

\begin{tabular}{lll}
\hline & SAT & VAT \\
\hline $\begin{array}{ll}\text { Adiponectin } \\
\text { Non-obese }\end{array}$ & $1(0.877-1.523)$ & $2.421(1.324-2.617)$ \\
$\quad$ Obese & $0.293(0.270-0.328)^{\mathrm{b}}$ & $0.075(0.027-0.600)^{\mathrm{b}, \mathrm{c}}$ \\
FOX01 & & \\
$\quad$ Non-obese & $1(0.821-1.181)$ & $0.422(0.315-0.621)^{\mathrm{c}}$ \\
$\quad$ Obese & $0.701(0.650-0.908)$ & $0.310(0.275-0.378)^{\mathrm{c}}$ \\
$\begin{array}{l}\text { PPAR } \gamma \\
\quad \text { Non-obese }\end{array}$ & $1(0.617-1.364)$ & $0.232(0.221-0.279)^{\mathrm{c}}$ \\
$\quad$ Obese & $0.731(0.507-1.298)$ & $0.147(0.077-0.265)^{\mathrm{c}}$ \\
$\begin{array}{l}\text { SIRT1 } \\
\text { Non-obese }\end{array}$ & $1(0.404-1.169)$ & $0.348(0.175-0.524)$ \\
$\quad$ Obese & $0.647(0.420-1.285)$ & $0.705(0.288-0.933)$ \\
\hline
\end{tabular}

aThe relative mRNA expression values are shown as median values (25th and 75th percentile). Relative expressions were normalized against $\beta$-2-microglobulin $(\Delta \mathrm{Ct})$ and calibrated to the mean value of SAT $\left(2^{-{ }^{-} \Delta \mathrm{Ct}}\right)$ of non-obese group.

bStatistical difference between non-obese and obese subjects performing the Mann-Whitney U test. $P<0.05$ was considered statistically significant.

cStatistical difference between SAT and VAT using Wilcoxon test.

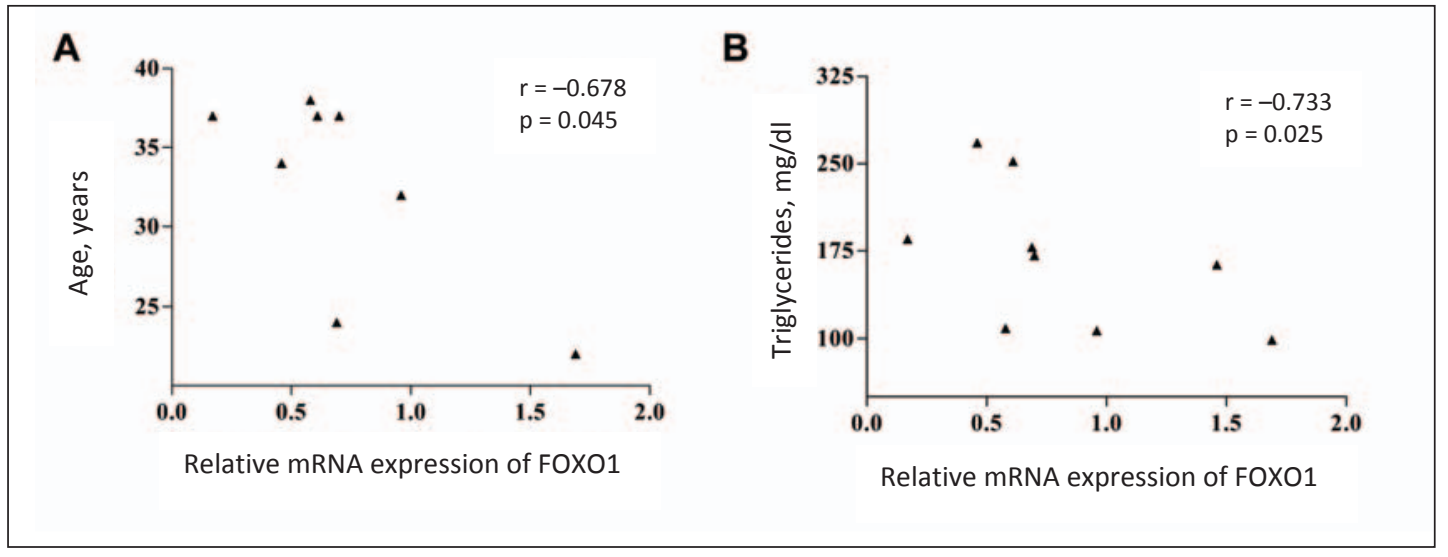

Fig. 1. Correlation between the relative mRNA expression of FOXO1 in subcutaneous adipose tissue of A class III obese subjects and age and $\mathbf{B}$ serum triglycerides levels.

\section{Discussion}

The regional distribution of adipose tissue is associated with profound physiological changes in obesity. Human VAT and SAT display differences in metabolic and biochemical properties as well as differences in gene expression profiles [23]. In the present study, we evaluated the mRNA expression levels of adiponectin, FOX01, PPAR $\gamma$, and SIRT1 in VAT and SAT of class III obese and non-obese subjects. 
In our study, the obese subjects had lower expression of adiponectin in VAT when compared to SAT. This profile was not observed in non-obese subjects who showed no difference between fat depots. Incubated samples of VAT from obese subjects exhibited significantly lower expression of adiponectin than those of SAT [24]. Moreover, adiponectin released by visceral adipocytes of obese women is significantly reduced when compared to subcutaneous adipocytes [25].

A decreased mRNA expression of adiponectin in adipose tissue has been reported in obesity [26]. We found that adiponectin mRNA expression in VAT was 32-fold higher in the non-obese when compared to obese subjects. The same tendency was observed in SAT, where adiponectin levels were 3.4 -fold higher in the non-obese. These results agree with a previous study [24] that showed higher adiponectin mRNA expression in VAT in lean than in obese subjects. Furthermore, the plasma concentrations of adiponectin in obese subjects were significantly lower than in non-obese [27]. Still the mechanism underlying the decreased adiponectin production in obesity remains unknown. Nevertheless, plasma adiponectin levels in obese subjects were found to be inversely correlated to circulating levels of IL-6 and TNF- $\alpha$, inflammatory cytokines associated with obesity [28, 29]. Studies in vitro have shown that TNF- $\alpha$ has an inhibitory effect on adiponectin mRNA levels in adipose tissue [28,30]. Adiponectin levels also are negatively correlated to adipocyte size (hypertrophy of adipocytes). Hypertrophy adipocytes in VAT are associated with many of the most common metabolic diseases, including insulin resistance and obesity [4]. Therefore, we hypothesized that adiponectin-reduced levels in VAT can be triggered by a pro-inflammatory state common in obesity. In addition, in our recent work, we found that resveratrol can stimulate adiponectin mRNA expression in visceral adipose cells of obese individuals, reverting the low expression [18]. However, more studies are necessary to confirm the relation of adiponectin with a pro-inflammatory state in visceral adiposity. In this way, the down-regulation of adiponectin mRNA expression in VAT of obese individuals could be related to insulin resistance development in obesity.

Analyses of FOXO1 and PPAR $\gamma$ mRNA levels showed minor expression in VAT compared to SAT in both groups (non-obese and obese). The FOX01 has been shown to be a mediator of the effect of insulin, glucose homeostasis and adipocytes differentiation [13, 31]. Although the FOXO1 isoform is known to play a key role in adipogenesis, its physiologic role in adipose tissue remains unclear [32]. A study that evaluated FOX01 expression in adult porcine model also found that FOXO1 mRNA expression was higher in SAT than in VAT [33]. FOXO1 haploinsufficiency seems to protect against insulin resistance and these effect may be explained by enhance of PPAR $\gamma$ [32]. With respect to PPAR $\gamma$, Giusti et al. [34] detected higher mRNA levels in SAT compared to VAT in obese women (BMI $>35 \mathrm{~kg} / \mathrm{m}^{2}$ ). In SAT, PPAR $\gamma$ agonists such as thiazolidinediones promote adipocyte differentiation (hyperplasia), causing an insulin sensitivity improvement [35]. On the other side, adipocyte hyperplasia in SAT is related to insulin resistance [4]. In our study, obese and non-obese individuals presented lower levels of FOXO1 and PPAR $\gamma$ in VAT compared to SAT, and this profile was accompanied by unaltered SIRT1 mRNA expression. Although FOXO could reduce the expression of PPAR $\gamma$ through interaction with other proteins, it also seems to bind directly to PPAR $\gamma$, to disrupt its DNA binding ability and to interfere with promoter DNA occupancy of this receptor [32]. Thus, the patterns of expression of FOXO1 and PPAR $\gamma$ may predispose to reduced action of PPAR via direct repression by FOXO1, promoting equal susceptibility to insulin sensitivity disorders. Because of this expression patterns, we believe that obesity-related co-morbidities could be related to low levels of adiponectin rather than to the the expression of PPAR $\gamma$ and FOXO1.

The pattern of FOXO1 mRNA expression in SAT has a significant inverse correlation with age of obese subjects, and this result was not observed in non-obese subjects. A study that compared FOXO1 mRNA expression in SAT of 1-day-old and 180-day-old pigs observed 
that FOX01 expression was higher in the youngest group [33]. The FOXO factors interact with several other transcription factors (NF-kB and p53) and, thus, can regulate the cellular survival responses, including metabolic stress resistance and cell-cycle responses and, ultimately, longevity [36, 37]. In this way, obesity seems to interfere in longevity, and this situation could be mediated by FOXO1 expression. The FOXO1 mRNA expression in obese SAT also showed inverse correlation with serum triglycerides. Zhang et al. [38] found modestly lower triglyceride levels in transgenic mice that express an active form of FOX01 in the liver. This study also showed that expression of lipoprotein lipase is increased in the liver of FOX01 transgenic mice, which can enhance the breakdown of triglycerides and metabolism of fatty acids [38]. Nonetheless, from the clinical point of view further studies on the molecular mechanism of FOX01 action in adipose tissue are important.

This study evaluated the mRNA expression of some genes, but it will be necessary to know more about protein translation in the future. This work deals with transcriptional control of different adipose tissues in obese and non-obese individuals. The results reveal an equal pattern of SIRT1 and a different pattern of adiponectin, FOXO1 and PPAR $\gamma$ mRNA expression in SAT and VAT. , As seen in other research models, our data suggest also metabolic differences among the different adipose depots. The decreased mRNA expression of these genes in VAT, responsible for central adiposity, may be associated with an increased risk of obesity and co-morbidities.

In conclusion, the patterns of gene expression in adipose tissue of non-obese and obese individuals will contribute to understand the pathogenesis of obesity and related disorders. The knowledge of these genes' modulation may be important to implement therapeutic research in a specific manner.

\section{Acknowledgments}

This work was supported by research grants from Conselho Nacional de Pesquisa (CNPq) and Fundação de Apoio a Pesquisa do Rio Grande do Sul (FAPERGS). Dr. R. Margis is the recipient of a research fellowship from Conselho Nacional de Desenvolvimento Científico e Tecnológico (CNPq).

\section{Disclosure Statement}

There is no financial interest to report.

\section{References}

1 Friel S, Chopra M, Satcher D: Unequal weight: equity oriented policy responses to the global obesity epidemic. BMJ 2007;335:1241-1243.

2 Forsy the LK, Wallace JMW, Livingstone MBE: Obesity and inflammation: the effects of weight loss. Nutr Res Rev 2008;21:117-133.

3 Lean ME: Pathophysiology of obesity. Proc Nutr Soc 2000;59:331-336.

- 4 Bays HE, González-Campoy JM, Bray GA, Kitabchi AE, Bergman DA, Schorr AB, et al: Pathogenic potential of adipose tissue and metabolic consequences of adipocyte hypertrophy and increased visceral adiposity. Expert Rev Cardiovasc Ther2008r;6:343-368.

- 5 Frederiksen L, Nielsen TL, Wraae K, Hagen C, Frystyk J, Flyvbjerg A, et al: Subcutaneous rather than visceral adipose tissue is associated with adiponectin levels and insulin resistance in young men. J Clin Endocrinol Metab 2009;94:4010-4015.

- 6 Veilleux A, Laberge PY, Morency J, Noël S, Luu-The V, Tchernof A: Expression of genes related to glucocorticoid action in human subcutaneous and omental adipose tissue. J Steroid Biochem Mol Biol 2010;122:28-34.

7 Ahmed W, Ziouzenkova O, Brown J, Devchand P, Francis S, Kadakia M, et al: PPARs and their metabolic modulation: new mechanisms for transcriptional regulation? J Intern Med 2007;262:184-198.

8 Kubota N, Terauchi Y, Miki H, Tamemoto H, Yamauchi T, Komeda K, et al: PPAR gamma mediates high-fat diet-induced adipocyte hypertrophy and insulin resistance. Mol Cell 1999;4:597-609. 
Hammes et al.: Parallel Down-Regulation of FOXO1, PPARg and Adiponectin mRNA

Expression in Visceral Adipose Tissue of Class III Obese Individuals

- 9 Rogue A, Spire C, Brun M, Claude N, Guillouzo A: Gene expression changes induced by PPAR gamma agonists in animal and human liver. PPAR Res 2010 Jan;2010:325183.

$\checkmark 10$ Ouchi N, Parker JL, Lugus JJ, Walsh K: Adipokines in inflammation and metabolic disease. Nat Rev Immunol 2011;11:85-97.

-11 Côté M, Mauriège P, Bergeron J, Alméras N, Tremblay A, Lemieux I, et al: Adiponectinemia in visceral obesity: impact on glucose tolerance and plasma lipoprotein and lipid levels in men.J Clin Endocrinol Metab 2005;90:1434-1439.

12 Gross DN, Wan M, Birnbaum MJ: The role of FOXO in the regulation of metabolism. Curr Diab Rep 2009;9: 208-214.

13 Kitamura T, Nakae J, Kitamura Y, Kido Y, Iii WHB, Wright CVE, et al: The forkhead transcription factor Foxo1 links insulin signaling to $\mathrm{Pdx} 1$ regulation of pancreatic $\beta$ cell growth. J Clin Invest 2002;110:1839-1847.

14 Biggs WH, Meisenhelder J, Hunter T, Cavenee WK, Arden KC: Protein kinase B/Akt-mediated phosphorylation promotes nuclear exclusion of the winged helix transcription factor FKHR1. Proc Natl Acad Sci U S A 1999;96:7421-7426.

15 Armoni M, Harel C, Karni S, Chen H, Bar-Yoseph F, Ver MR, et al: FOX01 represses peroxisome proliferatoractivated receptor-gamma1 and -gamma2 gene promoters in primary adipocytes. A novel paradigm to increase insulin sensitivity. J Biol Chem 2006;281:19881-19891.

16 Colak Y, Ozturk O, Senates E, Tuncer I, Yorulmaz E, Adali G, et al: SIRT1 as a potential therapeutic target for treatment of nonalcoholic fatty liver disease. Med Sci Monit 2011;17:HY5-9.

17 Picard F, Kurtev M, Chung N, Topark-Ngarm A, Senawong T, Machado De Oliveira R, et al: Sirt1 promotes fat mobilization in white adipocytes by repressing PPAR-gamma. Nature 2004;429:771-776.

$\checkmark 18$ Costa CDS, Hammes TO, Rohden F, Margis R, BortolottoJW, Padoin AV, et al: SIRT1 transcription is decreased in visceral adipose tissue of morbidly obese patients with severe hepatic steatosis. Obes Surg 2010;20: 633-639.

19 Bäckesjö C-M, Li Y, Lindgren U, Haldosén L-A: Activation of Sirt1 decreases adipocyte formation during osteoblast differentiation of mesenchymal stem cells. Cells Tissues Organs 2009;189:93-97.

20 Qiao L, Shao J: SIRT1 regulates adiponectin gene expression through Foxo1-C/enhancer-binding protein alpha transcriptional complex. J Biol Chem 2006;281:39915-39924.

21 Wallace TM, Matthews DR: The assessment of insulin resistance in man. Diab Med 2002;19:527-534.

-22 Livak KJ, Schmittgen TD: Analysis of relative gene expression data using real-time quantitative PCR and the 2(-Delta Delta C(T)) Method. Methods 2001 Dec;25:402-8.

23 Barth S, Klein P, Horbach T, Dötsch J, Rauh M, Rascher W, et al: Expression of neuropeptide Y, omentin and visfatin in visceral and subcutaneous adipose tissues in humans: relation to endocrine and clinical parameters. Obes Facts 2010;3:245-251.

24 Lihn AS, Bruun JM, He G, Pedersen SB, Jensen PF, Richelsen B: Lower expression of adiponectin mRNA in visceral adipose tissue in lean and obese subjects. Mol Cell Endocrinol 2004;219:9-15.

25 Drolet R, Bélanger C, Fortier M, Huot C, Mailloux J, Légaré D, et al: Fat depot-specific impact of visceral obesity on adipocy te adiponectin release in women. Obesity (Silver Spring) 2009;17:424-430.

-26 Statnick MA, Beavers LS, Conner LJ, Corominola H, Johnson D, Hammond CD, et al: Decreased expression of apM1 in omental and subcutaneous adipose tissue of humans with type 2 diabetes. Int J Exp Diab Res 2000; 1:81-88.

27 Arita Y, Kihara S, Ouchi N, Takahashi M, Maeda K, Miyagawa J, et al: Paradoxical decrease of an adiposespecific protein, adiponectin, in obesity. Biochem Biophys Res Commun 1999;257:79-83.

28 Bruun JM, Lihn AS, Verdich C, Pedersen SB, Toubro S, Astrup A, et al: Regulation of adiponectin by adipose tissue-derived cytokines: in vivo and in vitro investigations in humans. Am J Physiol Endocrinol Metab 2003;285:E527-33.

-29 Antuna-Puente B, Feve B, Fellahi S, Bastard J-P: Adipokines: the missing link between insulin resistance and obesity. Diab Metab 2008;34:2-11.

-30 Fasshauer M, Klein J, Neumann S, Eszlinger M, Paschke R: Hormonal regulation of adiponectin gene expression in 3T3-L1 adipocytes. Biochem Biophys Res Commun 2002;290:1084-1089.

-31 Nakae J, Kitamura T, Kitamura Y, Biggs WH, Arden KC, Accili D: The forkhead transcription factor Foxo1 regulates adipocyte differentiation. Dev Cell 2003;4:119-129.

-32 Kim JJ, Li P, Huntley J, Chang JP, Arden KC, Olefsky JM: FoxO1 haploinsufficiency protects against high-fat peroxisome proliferator - activated receptor $\gamma$ activation in adipose tissue. Diabetes 2009;58:1275-1282.

-33 Pang W-J, Yu T-Y, Bai L, Yang Y-J, Yang G-S: Tissue expression of porcine FoxO1 and its negative regulation during primary preadipocyte differentiation. Mol Biol Rep 2009;36:165-176.

-34 Giusti V, Verdumo C, Suter M, Gaillard RC, Burckhardt P, Pralong F: Expression of peroxisome proliferator - activated tissue of obese women. Diabetes 2003;52:1673-1676.

-35 Sewter CP, Blows F, Vidal-Puig A, O’Rahilly S: Regional differences in the response of human pre-adipocytes to PPARgamma and RXRalpha agonists. Diabetes 2002;51:718-723.

-36 Salminen A, Ojala J, Huu skonen J, Kauppinen A, Suuronen T, Kaarniranta K: Interaction of aging-associated signaling cascades: inhibition of NF-kappaB signaling by longevity factors FoxOs and SIRT1. Cell Mol Life Sci 2008;65:1049-1058.

37 Van Der Horst A, Burgering BMT: Stressing the role of FoxO proteins in lifespan and disease. Nat Rev Mol Cell Biol 2007;8:440-450.

-38 Zhang W, Patil S, Chauhan B, Guo S, Powell DR, Le J, et al: Fox01 regulates multiple metabolic pathways in the liver: effects on gluconeogenic, glycolytic, and lipogenic gene expression. J Biol Chem 2006;281:1010510117. 